DOI: https://10.15407/kvt197.03.080

UDC 519.216.3-008.1+616.132.2-089

S.I. KIFORENKO ${ }^{1}$, DSc (Biology), Senior Researcher,

Leading Researcher of the Department of Mathematical and Technical

Methods Application in Biology and Medicine

e-mail: skifor@ukr.net

T.M. HONTAR ${ }^{\mathbf{1}}$, PhD (Biology), Senior Researcher,

Senior Researcher of the Department of Mathematical and Technical

Methods Application in Biology and Medicine

e-mail: gtm kiev@ukr.net

V.L. ORLENKO ${ }^{2}$, PhD (Medicine), Senior Researcher,

Head of Scientific-Advisory Department

of Ambulatory and Preventive Care for Patients with Endocrine Pathology

e-mail: orleva@ukr.net

K.Y. IVASKIVA ${ }^{2}$, $\mathrm{PhD}$ (Medicine),

Senior Researcher of Scientific-Advisory Department

of Ambulatory and Preventive Care

for Patients with Endocrine Pathology

e-mail: k_iva@ukr.net

T. A. OBELETS ${ }^{1}$,

Junior Researcher of the Department of Mathematical and Technical

Methods Application in Biology and Medicine

e-mail: obel.tet@gmail.com

${ }^{1}$ International Research and Training Centre for Information Technologies

and Systems of the National Academy of Sciences of Ukraine

and Ministry of Education and Science of Ukraine,

40, Acad. Glushkov av., Kyiv, 03187, Ukraine

${ }^{2}$ State Institution "V.P. Komisarenko Institute of Endocrinology and Metabolism of NAMS of Ukraine”, 69, Vyshgorodska st., Kyiv, 04114, Ukraine

\title{
INFORMATION TECHNOLOGY FOR SUPPORTING SELF-CONTROL IN THE FORMATION OF A RATIONAL LIFESTYLE FOR DIABETICS PATIENTS
}

Introduction. Modern Diabetes mellitus is dangerous, chronic endocrine disease that originates from the disorder of metabolism, connected primarily with violation of carbohydrate exchange. Providing the necessity of independent self-control of health status of diabetes patients is the urgent problem of present time. The use of information technologies and mobile medicine facilitates enhancing the efficiency of self-control of health status by the patient.

The purpose of the paper is to develop a combined information technology to enhance the efficiency of glycemic self-control in case of diabetes at different stages of treatment. 
Results. We offer the algorithm of determination of the state of glycaemia regulation system based on the analysis of test results of glucose tolerance and the extended classification scale of glycaemia control (norm, violated tolerance (non-obvious diabetes, latent form, risk zone) that enhances the split ability of standardized methodology and enables timely measures of prophylactic actions to prevent real violations in glycaemia control system. An algorithm is implemented into software for desktops, tablets and mobiles under Android OS.

The developed information technology of decision-making support to choose an adequate mode of activity and meals for patients with diabetes helps to calculate the misbalance between energy gained by chosen menu (by the set of foods and dishes) and energy spent at the different types of the pre-arranged activity (physical, intellectual etc.).

Conclusions. Introduction of the designed algorithm in mobile devices is aimed to facilitate the availability of early diagnostics of violations in carbohydrate regulation system that may assist to reduce risks of emergence of obvious forms of diabetes mellitus. The use in the designed technology the principle of the external combined adjustment, that unites positive features of adjustment by disturbance with adjustment with feedback provides the possibility to enhance efficiency of self-control of the health status for the patient. The technology is implemented for desktops, tablets and mobiles on Android OS and enables access to information for the user with different degree of violation in carbohydrate exchange adjustment at the state of preambulatory help and during the treatment.

Keywords: information technology, diabetes mellitus, self-control of patient's health, management principles, M-medicine mobile media: information technology, self-monitoring of patient's health, management principles, mobile applications.

\section{INTRODUCTION}

Diabetes mellitus (DM) is dangerous chronic endocrine disease that originates from the disorder of metabolism, primarily associated with violation of carbohydrate exchange. Next to cardiovascular and oncologic diseases it occupies one of the leading places on medical-social scale. Starting from 50 -ies of $X^{\text {th }}$ century we may observe the constant increase of morbidity, spreading and death rate caused by this disease; the problem has been studied in many publications of leading diabetologists [1-4]. According to the estimates of the International Diabetes Federation (IDF) about 425 million people in the whole world suffer from diabetes. If nothing is done, the number of people with diabetes may rise to 629 million to 2045 that makes almost 6,5\% planet population [5]. World Health Organization relates this disease to the class of noninfectious epidemic $[6,7]$.

In Ukraine diabetes is one of the wide-spread diseases, and about 1,3 million people suffer from it; one fifth of patients are insulin dependent $[8,9]$. Prevalence of DM in Ukraine in 2010 constitutes 7,6\%, while in the year of 2030 it is expected to reach $9 \%$ with the amount of patients, if corresponding measures won't be taken, grows up to $35,5 \%$ [10].

As diabetes is regarded to be a chronic disease that does not provide permanent control from the side of a doctor, thus in such situation this function has to be fulfilled by a patient. It serves the WHO recommendations related to the change of paradigm of rendering assistance in such diseases, focused to the change of accents in the treatment process. Now the advantage in decision-making related to the correction and support of the compensative state of such disease belongs to the patient $[11,12]$. The necessity of self-control for patients with diabetes is the urgent problem of present time [13-16]. Now a doctor himself comes forward as an expert, while the final decision belongs to the patient, that he makes with the consideration of sociological, psychological and social factors. At the same time a 
problem of ethic nature arises, as grows the patient's responsibility for the diabetes status. The use of information technologies and mobile medicine facilitates the efficiency of patient self-control of the health status.

\section{PROBLEM STATEMENT}

It must be noted that deficit of sugar reducing hormone of insulin or resistance to it lies at the core of the carbohydrate exchange violation that makes impossible glucose absorption by tissues. The result of such disorder leads to a high level of glucose in blood and its variability. If fluctuations of glucose level have a long duration nature and occur often, it may result in vascular complications that end in early invalidilization and increase of death rate risks [17].

Commonly accepted therapy is basal-bolus regimen. Its core principle is based upon the attempt to recreate pancreas function related to its reaction on food. It is of replacement nature that consists in insulin discrete injections, coordinated with a carbohydrate constituent in the predictable meals under discrete control of glucose level in blood with the help of glucometers [18]. It must be noted that such treatment needs active participation from the side of a patient and depends fully on his motivation, skills, knowledge, while not all patients strictly follow doctor's recommendations. Even experienced patients with high motivation that fulfil all medical recommendations may face unsatisfactory results. It often depends on the individual peculiarities of regulation related to insulin-resistance, inflammations in the places of injections, allergy on a metal etc.

In treatment technical means that support insulin therapy are also often used, such as: portable devices of insulin infusion into hypoderm by pump (intensification of basal-bolus therapy) [19]. Such method does not eliminate the problems related to variability of the glycaemia, hypoglycemia situations and other complications as well. Devices of the continuous glucose monitoring (CGM) [20] are also widely used in treatment, and they provide information of the level of glycaemia during the day (each 5 minutes) and signal about dangerous hypo- and hypoglycemic situations to take timely measures for their reduction.

These technical developments considerably enhance the efficiency of glycemic control and are components that substantially contributes to the creation of artificial pancreas with closed feedback. It must be said that these data are not exact, because continuous monitoring system provides information about the level of glucose not in blood, but in an intercellular liquid; these levels are different, but the tendency of glycaemia dynamics is traced [21].

Such technical possibilities aimed to support glycaemia adjustment improved the process of standardized insulin therapy, but the problem of choosing the insulin dose that compensates carbohydrate component in meal is still relevant as the usage of glucometers, the systems of continuous monitoring and infusion systems do not eliminate the occurrence of hyperglycemic / hypoglycemic situations and of complications related to the practical use of these facilities (inflammation in the places of contact etc.). Furthermore, these technical devices are expensive enough and inaccessible to a wide public. 
Diabetes is a very complicated endocrine disease that needs various supports: not only pharmaceutical due to the synthesis of new medications, not only technical due to development of new devices, but, taking into account the challenges of modern time associated with the swift development of informative society, it needs information support (computer, mobile, Internet etc.). A patient is unable to fulfil the desire related with the realization of effective control of his diabetic status if he does not have an access to the necessary information tool. It should be mentioned that worldwide different diabetes researches pay a lot of attention to this very important problem. A great number of scientific reviews and thematic articles is dedicated to the problem of its actuality and to the research of the efficiency of use of information technologies, for example [22-25], where the implementation of information technologies aimed to improve diagnostics, treatment, monitoring and diabetes control is analyzed.

In survey-analytical works [23, 26-28] the information on efficiency and strategic prospect of the use of information telemedical component in the process of diabetes treatment is given.

World experience of the use of mobile telephones in medicine, including diabetology, is given in the following survey [29]. Technical capabilities of telephones and their closeness to the owner give real-time opportunity to get and to give necessary information to the user. Practically all modern smartphones have an organizers facilities that facilitate health control in case of chronic diseases, diabetes in particular. Smartphones are capable to register and to send to the doctor personal data of health status, meals, physical exercises, level of glucose and other parameters via means of communication (SMS, websites posting).

The majority of researches of the state of those diabetic patients who self-control their health status by monitoring a consumption of meal, physical activity and regular glucose measuring indicate improvement in control of this disease [22]. Generally, plenty of information about concrete applications of mobiles may be found in Internet. Along with the positive appraisal of the use of mobile devices whilst granting consultations to patients with DM, authors of survey [30] drew attention to problems associated with mobile expenses and their compensation to users. Together with advantages of information technologies some authors take notice on drawbacks in diabetes treatment, that are - higher cost of primary and technical services, complication of the use of computer and information systems for medical personnel and patients who do not have sufficient experience with computer devices. However, the demand for mobile applications constantly grows [31, 32].

The analysis of modern researches has shown that use of information technologies, in addition to traditional therapy, improves glycemic control with different efficiency at different clinical situations for patients with diabetes [22]. There is a need in integrated information techniques that combine simultaneously several technologies to provide diabetes treatment.

The purpose of the article is to develop integrated information technique of increasing the efficiency of glycemic self-control in case of diabetes at different stages of treatment process.

The information technique is designed to support decision-making for early diagnostics of the state of the carbohydrate exchange system and to provide selfcontrol of glycemic status subject to energetic balance. 


\section{INFORMATION SUPPORT OF DEFINITION OF THE CONDITION OF CARBOHYDRATE EXCHANGE SYSTEM ON PRE-NOSOLOGICAL STAGE}

The increase of diabetes dissemination is by and large related to its asymptomatic progress on the early stages of disease. For this reason, a person starts seeking advice from a doctor with a delay, when complications have already aroused. At this stage treatment is difficult and expensive. Due to this group of people who consider themselves to be relatively healthy as increased level of glucose does not affect the way of living, the amount of DM patients increase up to $15 \%$ annually [1] and dissemination expands. To win the battle against this disease and to take prevention measures against its complications it is crucial to provide an early determination of violations in carbohydrate exchange and timely detection of DM patients. The earlier disease is being identified, the more chances to preserve capacity, the more effective treatment will be.

In WHO Recommendations of 2011 a new diagnostic criterion based upon glycolized HbA1c hemoglobin is approved. Its application simplifies the identification of the asymptomatic stage of the disease. At the same time a new diagnostic scale is recommended: value $\mathrm{HbA} 1 \mathrm{c}>6,5 \%$ — corresponds to the diagnosis of diabetes mellitus; while $6,4 \%>\mathrm{HbA1c}>5,7 \%$ constitutes a high-risk group; and for $\mathrm{HbAlc}$ $<5,7 \%$ - is the norm [33]. Introduction the methodology of determination of $\mathrm{HbA} 1 \mathrm{c}$ concentration into a practice of diagnostics of glycemic determination status substantially improved identification of pre-clinic stages of diabetes, and its treatment and support at the stage of compensation disregarding the fact that the evaluation according to this method is of accumulative character, as only time-period of three month deviations in adjustment is taken into consideration.

Besides, in practice of DM treatment glucose tolerance test (GTT) based on laboratory analysis data of glycaemia by three information points is widely used: on an empty stomach, in one hour and in two hours on the background of the per oral test glucose loading. Obtained test glycemic profile of dynamics of blood sugar serves as the indicator of quality of functioning of the system of glycaemia adjustment. As a result, three states of the glycemic adjustment system depending on the values of glycaemia concentration on the time scale, that are - norm, violated tolerance, diabetes [34, 35].

Must be noted that diagnostic properties of glucose-tolerance test can be increased due to the improvement of its results processing. The algorithm of determination of the status of glycaemia adjustment system based on calculation and analysis of the linear-weighted sum of the amounts of deviations in test measuring of glucose concentration that differs from the average glycemic norm for healthy people (during the same physical activity) in exactly those three points: on an empty stomach, in one hour and in two hours after the test glucose loading (Fig.1) is offered. With the help of designed diagnostic scale, it is possible to define not only the status of glycaemia adjustment system using a standard diagnostic range: norm, violated tolerance (non-obvious diabetes, latent form) and diabetes, but also to further define a risk zone [34]. A presence of that additional range in the diagnostic appraisal enhance the resolving powerof standard methodology that enables to provide timely measures to prevent actual violations in glycaemia adjustment system. The early detection of persons with those violations at the preclinical stage will assist the reduction of disease dissemination. 
The implementation of the designed algorithm into mobile devices is aimed to increase the availability of the service of early diagnostics of violations in carbohydrate exchange system that may assist the risk reduction of the emergence of explicit forms of diabetes disease.

This algorithm is implemented in three software variants: for computers, tablets and for mobile devices on Android OS. The screen forms for mobile implementation are shown (Fig. 2).

$\delta$ - Criterion for quantifying the degree of violations in carbohydrate metabolism

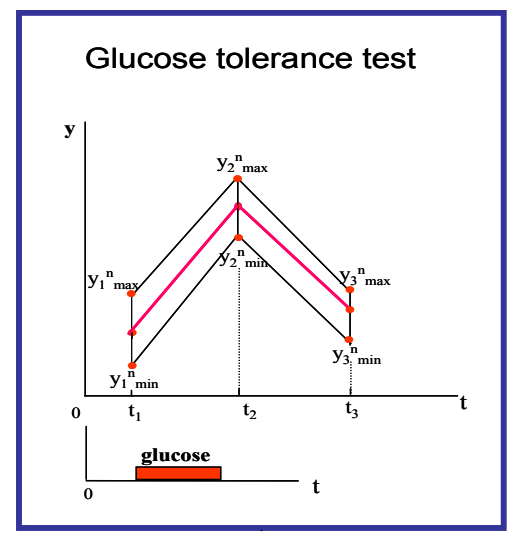

$$
\begin{aligned}
& \delta=\alpha_{1}\left(y_{1}-y_{1 N}\right)+\alpha_{2}\left(y_{2}-y_{2 N}\right)+\alpha_{3}\left(y_{3}-y_{3 N}\right) \\
& \alpha_{i}=\left(y_{i}^{n}{ }_{\text {max }}-y_{i}^{n}{ }_{\text {min }}\right) /\left(y_{\text {max }}-y_{\text {min }}\right) \\
& 0<\delta=<15 \quad-\text { norm } \\
& 15<\delta=<25 \quad \text { - risk group } \\
& 25<\delta=<40 \quad-\text { impaired tolerance } \\
& \delta>40 \quad \text { - diabetes }
\end{aligned}
$$

Fig.1. Chart of determination of the status of glycaemia adjustment system

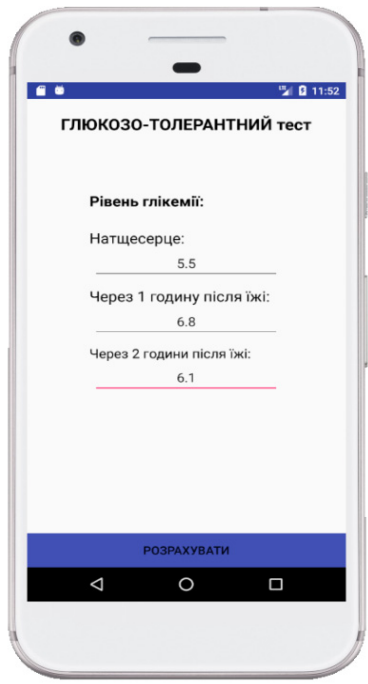

a)

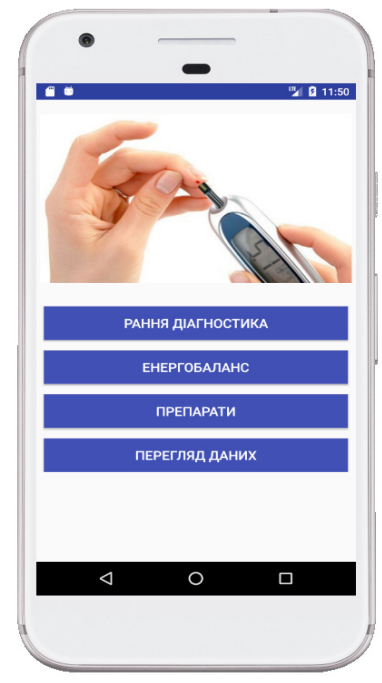

b)

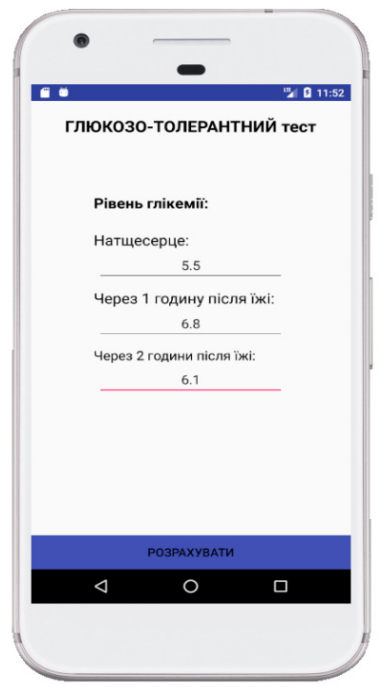

c)

Fig. 2. Screen forms for mobile implementation: a) window of choosing the module; b) initial data for test input; c) diagnostic window 


\section{INFORMATION SUPPORT OF GLYCEMIA SELF-CONTROL. ENERGY BALANCE}

In the course of evolution, a complex system of adjustment of carbohydrate exchange was formed to grant its energy needs. At the same time, it is necessary to maintain the concentration of glucose in blood within homoeostatic limits; the task that is carried out due to coordinated co-operation both - of nervous and endocrine mechanisms. That stable enough homoeostasis in a healthy organism counteracts against various external influences related to the periodic meals, physical and emotional activities, etc. [36, 37].

In terms of control theory [38] must be indicated that in the organism a quite complex and well-balanced automatic system of physiological control with hierarchical framework of direct and inverse relationship is established. A set of glucoreceptors sends the information about the level of glucose concentration to the central nervous system (hypophysis, hypothalamus), and from there via nervous fibers - to the pancreas that secretes a sugar-reducing hormone insulin, the activity of which increases, if glucose is in a hyperglycemic phase. In case of hypoglycemia a set of endocrine disruptors that perform contrinsular function - opposed to that of pancreas, and in this situation it assists the increase of glycemic level [37].

External glycemic control setting. In a healthy organism all these processes are executed automatically. In a pathological state at diabetes, when automatic physiology control is impaired, such control is replaced by the external therapeutic measures aimed to artificially recreate the perfect physiology adjustment.

For organization of artificial process of glycaemia control it would be useful to take advantage of control theory terminology. For this purpose, it is necessary:

- to have a clear idea about the purpose necessary to attain control measures, desirable range of glycaemia values that has to be attained;

- to have information about the influence at least of basic external factors, such as - meals, physical activities that can be considered, although there is an enormous amount of emotional accidents that is impossible to envisage,

- to have data about the state of the object in control - current glycaemia level at the moment of control measures to be taken.

The principle of external control with feedback. Depending on the availability of information mentioned above the approaches of control differ [38]. In case of a technical feasibility to get continuous glycemic control and transportation of basic therapeutic substances into an organism - as insulin, contra-insular factors - then the principle of automatic control with a feedback is being implemented. In case a control device obtains delayed data, one should implement the principle of adaptive control involving feedback contour of prognosis model [39]. At the same time the system reacts on the fact of deviation in glycemic level from its desired value, regardless reasons that caused it.

Feedback is a way to artificial pancreas. The ways of glucose measuring that may replace glucoreceptors are able to implement an adjustment option with feedback, that is the initial stage to creation of artificial pancreas. Lately the design and testing of such devices are being conducted, while problems of making a system of artificial glycaemia adjustment were defined $[21,39,40]$. On Fig.3 the fundamental diagram of control system with feedback (artificial pancreas) is presented. 


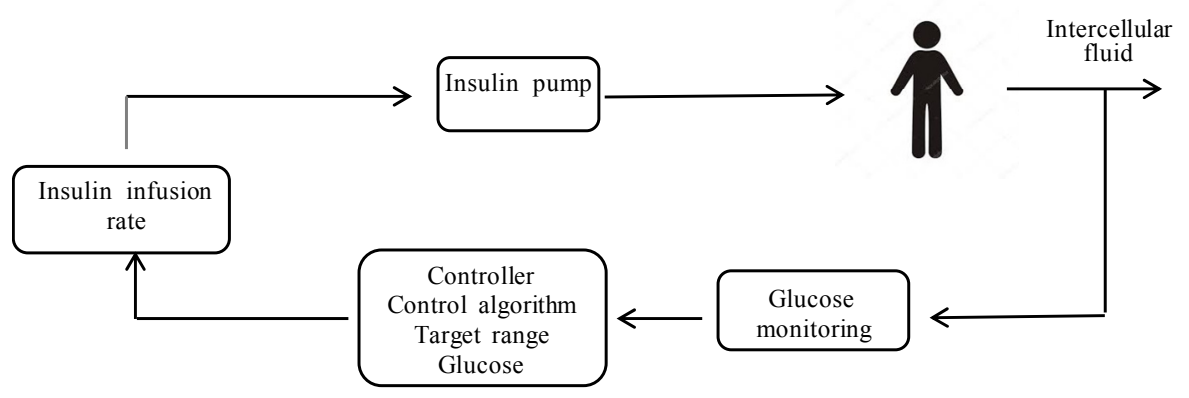

Fig. 3. A functional diagram of control process managing deviation with a feedback

Principle of external control based on disturbance. In case of lack of automatic control, when the correction of the status runs discretely according to a certain time schedule with some delay - as there is no possibility to work out timely glucose measuring - an attempt to use terminology of automatic control theory would be incomplete, if external influences onto a carbohydrate constituent both — at meals and data of energy consumption during different types of activity are not being considered. To solving such a problem in everyday life the modern information space offers plenty of databases on food and energy consumption with the information offered in article and on Internet web-sites [41, 42]. The possibility of the quantitative consideration of these factors, if spoken in terms of control theory, recreates that part of control process that is called adjustment by disturbance. In such a case the system is invariant towards its internal state and does not depend on glucose concentration in blood because such information is missing. A positive issue of such control grounds on the fact that then the compensation of disturbance is implemented with prior warning of its effect onto glycemic level, in other words before this disturbance affects control parameter. The functional diagram of such a control process is given in Fig. 4.

The weaknesses of control by disturbance lie in the fact that the system enables only a limited number of disturbances. For the designed technology they are - meals and physical activity. An attention must be paid to the fact that the dependence of control measures (doses of insulin) from external influences (meals and activity) is quite complex one and cannot be accordingly realized exactly. Besides, other external influences onto adjustment system may exist as well, that are hard to consider, e.g. emotional disturbances. Another drawback of application with such control principle is that in this case the system becomes invariant towards internal health profile. In our case it means that deviations in adjusted parameter of glycaemia from a desirable level undoubtedly exist, but they are not considered in calculation of a controlled insulin dose according to this control principle.

Principle of the external combined adjustment. Information content in external control constituent taken from databases is given in such a way that user takes for granted as a basis for qualitative energy supply and energy spending should be accordingly complemented by glucose-in-blood measuring before a meal. Data input of these measurements into the calculation of insulin bolus may help to recreate and quantitatively consider smooth mechanisms of glycemic adjustment, that take place in a healthy organism. And in terms of control theory this is the combined adjustment that consists of two constituents - 1) feedback adjustment of glycaemia deviation from a desirable level and 2) adjustment by 
disturbance. The principle that combines the positive features of adjustment by disturbance and a feedback by deviation is most precise one and has widespread use. A result of functional diagram complemented by the contour of the discrete feedback harmonized with meals is presented on Fig.4.

There are a few protocols of insulin therapy. The closest to the natural secretion of insulin by pancreas that reacts on meals is basical-bolus methodology that is widely used in practice of diabetes therapy. According to this methodology the correction of the compensatory insulin dose on a meal, calculated by carbohydrate choice added by additional dose of insulin depending on the glycaemia level before a meal [43] is assumed.

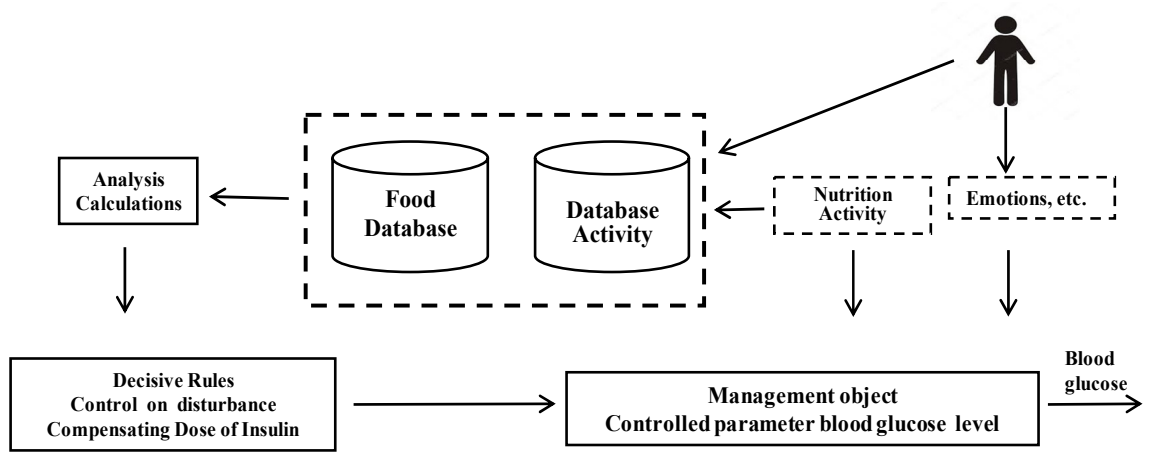

Fig. 4. Functional diagram of control by disturbance

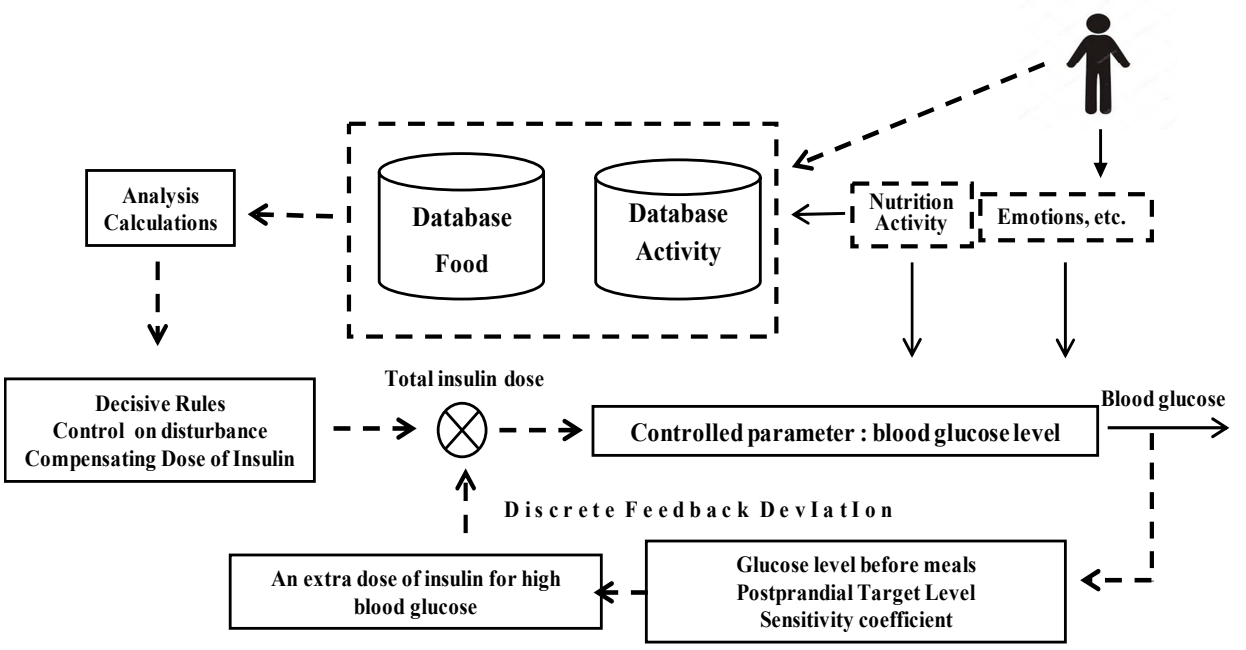

Fig. 5. Functional diagram of the combined control - a combination of adjustment by disturbance with feedback adjustment of glycaemia deviation from a desirable level 
Thus, basic principles of automatic control theory are applied to therapeutic measures of DM treatment however a discrete mode. The fundamental diagram of such a combined control is presented (Fig. 5).

\section{INFORMATION-STRUCTURAL MODEL}

Taking into account the fact that diabetes is chronic disease, while patient faces the problems in private and constantly needs information help, the following task is set: to work out information technology to support decision-making aimed to simplify, bring it closer to the consumer and to make accessible the necessary information with the help of modern computer and mobile means.

A basic factor in medical treatment that accompanies sugar-reducing therapy is a diet therapy. Patients with diabetes of the $1^{\text {st }}$ and the $2^{\text {nd }}$ types must thoroughly learn - first with the help of specialist, then independently - to calculate calories, carbohydrates and carbohydrate choice contained in meals, plan the meals according to individual needs that depend on the type of diabetes, anthropometric data, physical activity of patient and other factors. Principles of choosing a diet of a certain calorie content that meets energy consumption fundamentally depends on type of diabetes. In case of diabetes of the $1^{\text {st }}$ type it is crucial to coordinate carbohydrates in a chosen menu with the compensative dose of insulin that is calculated according to the amount of carbohydrate choice (CC) equivalent to the carbohydrate constituent in a meal. For diabetes of the $2^{\text {nd }}$ type, as it deals with violations of carbohydrate-adipose metabolism persons with excessive body mass have to calculate calories to further reduce. In both cases patients are bound to execute routine calculations that negatively influence the quality of everyday life.

To facilitate it plenty of computer programs and applications that contain necessary information are designed. However, such information is often ambiguous and contradictory. Information support for the developed technology is based on normative documents of Ministry of Health of Ukraine concerning norms of physiologic needs of population of Ukraine in basic foodstuffs and energy [44]. Data related to day's requirement in calorie equivalent for different age groups of adult population given in the article are approximated by equations of regression such as:

$$
\mathrm{Q}=\mathrm{A} * \mathrm{~W}+\mathrm{B}
$$

where: Q — is the day's requirement in calories excluding physical activity, $\mathrm{W}$ - is weight, A, B — are coefficients of regression.

The results of approximation are given in Table 1 .

Activity is considered according to the following formulas:

$\begin{array}{ll}\text { Very easy } & \mathrm{Q} 1=\mathrm{Q}+\mathrm{Q} / 6 \\ \text { Easy } & \mathrm{Q} 2=\mathrm{Q}+\mathrm{Q} / 3 \\ \text { Middle weight } & \mathrm{Q} 3=\mathrm{Q}+\mathrm{Q} / 2 \\ \text { Heavy } & \mathrm{Q} 4=\mathrm{Q}+2 \mathrm{Q} / 3 \\ \text { Very heavy } & \mathrm{Q} 5=\mathrm{Q}+2 \mathrm{Q}\end{array}$


Table 1. Coefficients of regression equations for the calculation of daily needs in a calorie equivalent for different age groups of adult population

\begin{tabular}{|c|c|c|c|c|}
\hline Equations & \multicolumn{4}{|c|}{$\mathrm{Q}=\mathrm{A} * \mathrm{~W}+\mathrm{B}$} \\
\hline & \multicolumn{2}{|c|}{ Men } & \multicolumn{2}{c|}{ Women } \\
\hline Age & A & B & A & B \\
\hline $18-29$ & 16,4 & 610,8 & 15,0 & 477,8 \\
\hline $30-39$ & 15,5 & 572,7 & 14,5 & 465,8 \\
\hline $40-59$ & 14,4 & 540,3 & 14,1 & 449,8 \\
\hline$\geq 60$ & 13,5 & 495,1 & 13,4 & 426,9 \\
\hline
\end{tabular}

Technological basis of the designed information technology grounds on the information-structural model of the problem focused on the division of all volume of knowledge according to a task organized into separate modules of logically-combinatory type and into modules of calculation procedures that represent their quality features and their specific use (Fig. 6).

The module of data processing provides the interpretation of results, conclusions and recommendations on calories in meals. According to these data the body weight index, recommended mass and weight misbalance are calculated, and those data obtained use as the basis for diagnostic conclusions ("Mass in norm", "Deficit of mass", "Higher norm", "Obesities of a 1,2,3 Degree").

A structural diagram illustrates algorithmically envisaged actions incorporated by logical sequence of allocated modules.

The module of input data contains:

- personal anthropometric data, type of diabetes, disease duration, type of activity according to professional activity of user (chosen from the list);

- glycaemia level before a meal, desirable glycaemia level (mmol/l).

Module "Energy balance" combines "Foods" and "Activity" databases.

These modules have a hierarchical structure, constituents of which are grouped and contain corresponding data characteristic for dietology and for the science of labor activity (with the consideration of a consumer basket, national cuisine etc.).

Basic information kernel of the module "Energy balance" consists databases (as dynamic tables with the calculation fields) of foods and types of activity with corresponding hierarchical organization (types, groups, kinds).

In the process of implementation rules of these bases according to the designed algorithms a misbalance between energy that comes into an organism together with the user chosen menu (the set of products and dishes) and energy that is spent during different types of the pre-arranged activity (physical, intellectual etc.) is calculated.

The output of work of this module is the value of calories in foods of chosen menu, carbohydrate constituent, carbohydrate choice and compensatory insulin dose that recreates the component adjustment by disturbance described higher.

The calculation of additional dose of insulin according to the results of deviation of glycaemia level before a meal from the desirable one realizes an adjustment constituent with feedback.

The result of a combined correction is the cumulative insulin dose. It is necessary to consider the individual sensitiveness of patient to the type of insulin, the coefficient of that is chosen personally. 


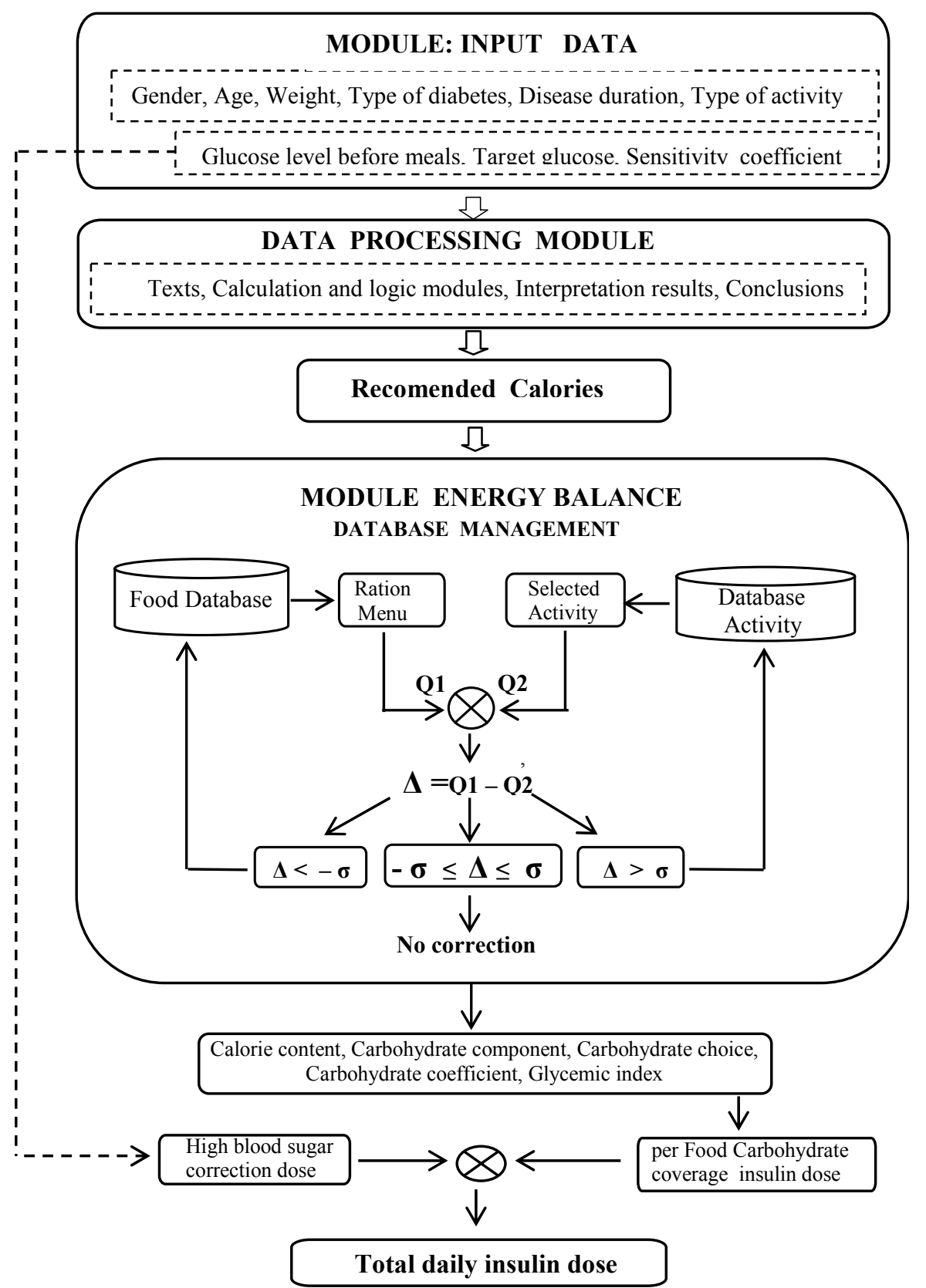

Fig. 6. Structural-algorithmic diagram of information technologies of decision-making to choose the menu adequate to energy consumption 
This technology is implemented in three modifications: for desktops, tablets and for mobile devices on Android [34]. The screen forms for mobiles are presented (Fig. 7).

The implementation of the designed technology in mobile Android applications brings closer information support to the user for the further independent practice of rules of harmonization of insulin therapy with building up an adequate energy balance in relation of energy supply with a meal and its further spending during pre-arranged activity in a calories equivalent.

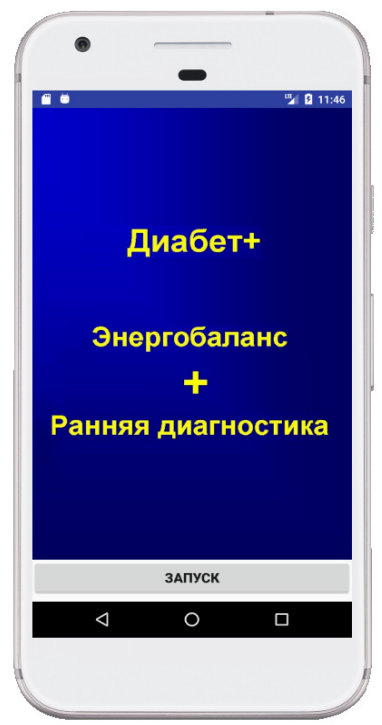

a)

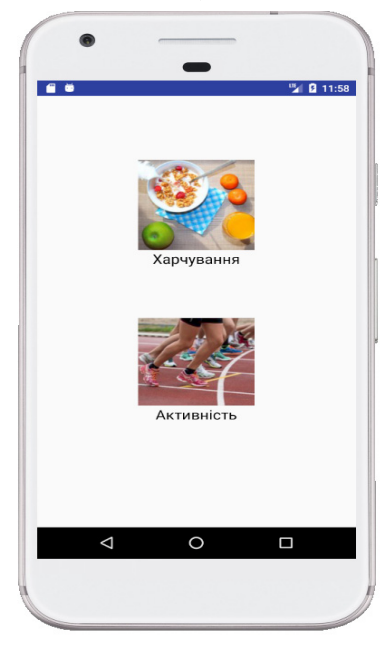

d)

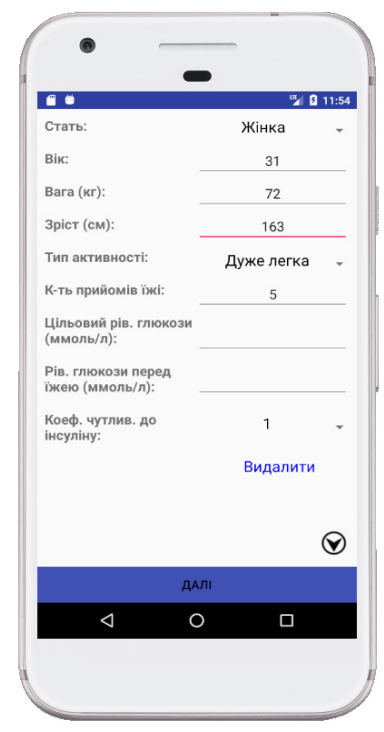

b)

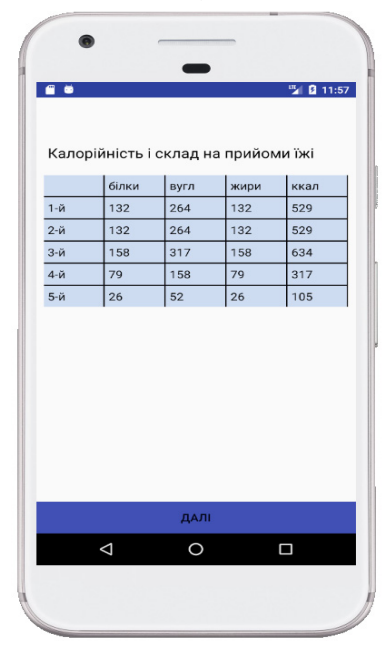

e)

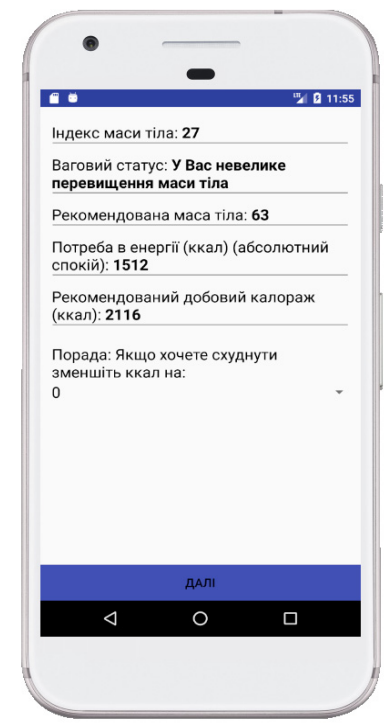

c)

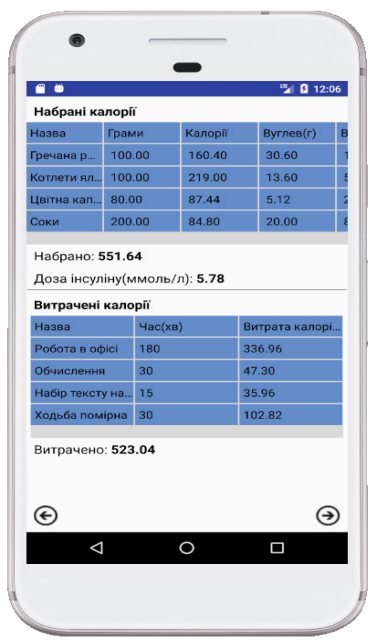

f)

Fig. 7. Screenshots for mobiles: a) starting window, b) input data, c) conclusions, d) choice of database (activity, foods), e) calculation of calories content and constituents (proteins, fats, carbohydrates) for each meal, f) tables of calories taken with meal and spent during pre-arranged activity and insulin dose 
The application of the designed combined technology aimed to support a decision-making in diabetology according to the different stages of treatment process (diagnostics, treatment, insulin therapy) with the use of computer facilities of different level of realization (computers, tablets, mobiles) gives an opportunity to enhance efficiency, to bring it closer to the user, to do more accessible an information help to the patient with the different degree of violation in carbohydrate exchange, both - at the stage of preclinical ambulatory help and during the treatment itself.It must be noted that if a correction of insulin dose is exceptional prerogative of treatment process, then a diet correctly chosen with the help of modern information technologies (mobile as well) is the component of decision-making support at all stages of treatment and in everyday's life.

The approbation of designed information technology was performed in V.P.Komissarenko Institute of Endocrinology and Metabolism in ambulatory care of DM patients and the results have shown positive influence on making a decision in the process of treatment.

\section{CONCIUSIONS}

Despite certain achievements in diabetology, diabetes mellitus remains a problematic disease and it needs careful and laborious therapeutic efforts and considerable financial costs to provide a patient an adequate level of life sustenance.

The offered algorithm of determination of the state of glycaemia adjustment system that grounds on the analysis of test results on glucose tolerance and on the extended classification scale of glycaemia adjustment — norm, risk zone, violated tolerance (latent form) and diabetes - enhances the resolving power of standardized methodology that enables timely to take necessary prophylactic measures to avoid real violations in the system of glycaemia adjustment.

The principle of the external combined adjustment that combines positive features of adjustment by disturbance with that with feedback is now admitted to be the most acceptable. And that implies its wider application in developing the information means of decision-making support to finer tuning of carbohydrate exchange system.

The developed information technology of decision-making support to choose an adequate mode of activity and meals for patients with diabetes provides making a decision at different treatment stages through the calculation of misbalance between energy gained by chosen menu (by the set of foods and dishes) and energy spent at the different types of the pre-arranged activity (physical, intellectual etc.). The technology is implemented into software for desktops, tablets and mobiles under Android OS. The use of such technology enables to enhance the efficiency of diabetes treatment and facilitates information help to the user with the different degree of violation in carbohydrate exchange adjustment.

\section{REFERENCES}

1. Dedov I.I. Diabetes mellitus is the most dangerous challenge to the world community. Bulletin of the Russian Academy of Medical Sciences. 2012. V. 67, no. 1, pp.7-13. (In Russian).

2. Jung H.S. Clinical Implications of Glucose Variability: Chronic Complications of Diabetes. Endocrinol Metab (Seoul). 2015, no. 30(2), pp. 167-74.

3. Dedov I.I., Shestakova M.V., Vikulova O.K., Zheleznyakova A.V., Isakov M.A. Diabetes mellitus in the Russian Federation: prevalence, incidence, mortality, carbohydrate metabolism parameters and structure of hypoglycemic therapy according to the Federal 
Register of Diabetes Mellitus, 2017 status. Diabetes mellitus. 2018, T.21, no. 3, pp. 144-159. (In Russian).

4. Efimov A.S., Orlenko V.L., Sokolova L.K. Diabetes mellitus and its complications. Journal. pract. doctor. 2003, no 2, pp.34-40. (In Russian).

5. IDF Diabetes Atlas 8th edition 2017 update. URL: https://www.diabete.qc.ca > getdocumen tutile > IDF-DA-8e-EN-finalR3

6. Diabetes. WHO 2018. URL: https://www.who.int/news-room/fact-sheets/detail/diabetes.

7. Pankov V.I. Diabetes mellitus: definition, classification, epidemiology, risk factors. International. Journal of Endocrinology. 2013, no. 7 (55). P. 55-60. (In Russian).

8. Diabetes in Ukraine. «Diaforum 2017». URL: https://www.unian.net/health/country/ 233891v-ukraine-bolee-1-mln-300-tyisyach-lyudey-jivut-s-saharnyim-diabetom.html. (In Ukrainian).

9. Shaw J.E., Sicree R.A., Zimmet P.Z. Diabetes Atlas: Global estimates of the prevalence of diabetes for 2010 and 2030. Diabetes Research and Clinical Practise. 2010, Vol. 87, pp. 4-14.

10. The prevalence of diabetes in Ukraine. URL: https://telegraf.com.ua/zhizn/zdorove/ 195284-rasprostranennost-saharnogo-diabeta-v-ukraine.html. (In Russian).

11. Innovative care for chronic conditions. Key elements for action: global report of the world health organization (WHO ,2003). URL: https://www.who.int/chp/knowledge/ ublications/ icccrussian.pdf/ua. (In Russian).

12. Inzucchi S.E., Bergenstal R.M., Buse J.B. [et al.] Management of Hyperglycemia in Type 2 Diabetes, 2015: A Patient-Centered Approach: Update to a Position Statement of the American Diabetes Association and the European Association for the Study of Diabetes. Diabetes Care. 2015. Vol. 38, no. 1, pp. 140-149.

13. Whitehead L, Seaton P. Whitehead L, Seaton P. The Effectiveness of Self-Management Mobile Phone and Tablet Apps in Long-term Condition Management: A Systematic Review. J Med Internet Res. 2016. Vol. 18(5):97.

14. Debon R., Coleone J.D., Bellei E.A., De Marchi A.C.B. Mobile health applications for chronic diseases: A systematic review of features for lifestyle improvement. Diabetes Metab Syndr. 2019. Vol. 13, no. 4, pp. 2507-2512.

15. Mamedov M.N. Self-monitoring in diabetes: the use of modern technology at home. Medical advice. 2016, no.13, pp.95-98. (In Russian).

16. Dreval A.V., Redkin Yu.A. The role of self-control in the treatment of diabetes. Russian medical journal. 2016, no. 1, pp. 38-40. (In Russian).

17. Balabolkin M.I., Klebanova E.M., Kreminskaya V.M. Treatment of diabetes and its complications (a guide for doctors). Moscow: Medicine, 2005. (In Russian).

18. Samson O.J., Bolshova O.V., Muz V.A. Features of diabetes self-control in children and adolescents. Clinical endocrinology and endocrine surgery. 2010, no. 2 (31), pp.42-47. (In Ukrainian).

19. Report of a seminar on pump insulin therapy. The Russian Diabetic AS-Society (June 23-26, 2012). URL: http://rda.org.ru/doc/poland2012.htm. (In Russian).

20. Dedov I.I., Shestakova M.V., Mayorov A.Yu. Algorithms for specialized medical care for patients with diabetes mellitus. 8th edition. Moscow: UP PRINT, 2017. (In Russian).

21. Karpel'ev V.A., Fedorov E.A., Filippov I. Yu., Shestakova M.V. Intraperitoneal infusion of insulin in diabetes mellitus: Towards an artificial pancreas. Diabetes mellitus. 2015, no. 3, pp.32-45. (In Russian).

22. Riazi H., Larijani B.,Langarizadeh, M. And L. Shahmoradi. Managing diabetes mellitus using information technology: a systematic review. J Diabetes Metab Disord. 2015. Vol. 14, p. 49.

23. Jackson C.L., Bolen S., Brancati F.L., Batts-Turner M.L., Gary T.L. A systematic review of interactive computer-assisted technology in diabetes care: interactive information technology in diabetes care. J Gen Intern Med. 2006. Vol. 21, no. 2, pp.105-110.

24. Saenz A., Brito M., Moron I., Torralba A., Garcia-Sanz E., Redondo J. Development and validation of a computer application to aid the physician's decision-making process at the start of and during treatment with insulin in type 2 diabetes: a randomized and controlled trial. J Diabetes Sci Technol. 2012. Vol. 6(3), pp. 581-8.

25. Tronko N.D., Halangot N.D. The use of computer systems and information technologies in practical diabetes. Endokrynolohiya. 2001, no. 1, pp.89-94. (In Russian). 
26. Marcolino M.S., Maia J.X., Alkmim M.B.M., Boersma E., Ribeiro A.L. Telemedicine application in the care of diabetes patients: systematic review and meta-analysis. Plos One. 2013. Vol. 8(11), e79246.

27. Adaji A., Schattner P., Jones K. The use of information technology to enhance diabetes management in primary care: a literature review. Informatics in Primary Care. 2008, no. 16 , pp. 229-37.

28. Siriwardena L.S.A.N., Sudarshana Wickramasinghe W.A, Dussantha Perera K.L, Marasinghe RB, Katulanda P, Hewapathirana R. A review of telemedicine interventions in diabetes care. $J$ Telemed Telecare. 2012, no. 18, pp. 164-168.

29. Chestnov O.P., Boytsov S.A., Kulikov A.A., Baturin D.I. Mobile healthcare: global experience and prospects. Preventative medicine. 2014, no. 17(4), pp 3-9. (In Russian).

30. Bree Holtz, Carolyn Lauckner. Diabetes management via mobile phones: a systematic review. Telemedicine and e-Healt. 2012. Vol. 18, no. 3, pp. 175-185.

31. Faraz S. Ahmad, Thomas Tsang. Diabetes Prevention, Health Information Technology, and Meaningful Use. American Journal of Preventive Medicine. 2013. Vol. 44, no. 4, pp. 357-363.

32. Pradeepa R., Prabu A.V., Jebarani S., Subhashini S., Mohan V. Use of a large diabetes electronic medical record system in India: clinical and research applications. $J$ Diabetes Sci Technol. 2011, no. 5(3), pp. 543-552.

33. World Health Organization. (2011). Use of glycated haemoglobin (HbAlc) in diagnosis of diabetes mellitus: abbreviated report of a WHO consultation.World Health Organization. URL: https://apps.who.int/iris/handle/10665/70523

34. Lavrenyuk N.V., Kiforenko S.I., Kotova A.B., Ivaskiva E.Yu. Information and computer support for decision-making in the early diagnosis of diabetes. Kibernetika $i$ vyčislitelnaâ tehnika. 2009, iss. 157, pp. 54-60. (In Russian).

35. Tronko M.D., Efimov A.S., Kravchenko V.Sh., Early diagnosis of diabetes mellitus and its complications. Doctor Info: Health Portal. 2003. URL: http://www/likarsnfo/ pro/43480/. (In Ukrainian).

36. Efimov A.S., Karabun P.M., Epshtein E.V. Obesity and diabetes mellitus. Kyiv: Health, 1987. (In Russian).

37. Efimov A.S., Orlenko V.L., Sokolova L.K. Diabetes mellitus and its complications. Zhurn. prakt. likarya. 2003, no. 2, pp. 34-40. (In Russian).

38. The principles of automatic control, their advantages and disadvantages. URL: https://studfiles.net/preview/4634773/page:13/. (In Russian).

39. Turksoy K., Cinar A. Adaptive control of artificial pancreas systems - a review. J Healthc Eng. 2014. Vol. 5(1), pp.1-22.

40. Cobelli C., Renard E., Kovachev B.P. Artificial pancreas: past, present, future. Diabetes. 2011. Vol. 60, pp. 2672-82.

41. Lebedeva O., Lebedev I. Counting calories. URL: http://calories.ru/cgi-bin/calc.pl. (In Russian).

42. Kadomsky Yu. Alphabet of diabetes. Point intensive insulin therapy of insulindependent diabetes mellitus. 2018. URL: http://www.juri.dia-club.ru. (In Russian).

43. School of diabetes. Learn to manage diabetes. URL: https: / https://shkoladiabeta.ru/.(In Russian).

44. On Approval of the Norms of Physiological Needs of the Population of Ukraine in the Basic Nutrients and Energy. Order of 09.03.2017 № 1073 of the Ministry of Health of Ukraine. URL: http://zakon2.rada.gov.ua/laws/show/z1206-17 (In Ukrainian).

\section{ЛІТЕРАТУРА}

Received 19.06.2019

1. Дедов И.И. Сахарный диабет - опаснейший вызов мировому сообществу. Becmник Российской Академии медичинских наук. 2012. Т. 67. №1. С.7-13.

2. Jung HS. Clinical Implications of Glucose Variability: Chronic Complications of Diabetes. Endocrinol Metab (Seoul). 2015. No. 30(2). P. 167-74. 
3. Дедов И.И., Шестакова М.В., Викулова О.К., Железнякова А.В., Исаков М.А. Сахарный диабет в Российской Федерации: распространенность, заболеваемость, смертность, параметры углеводного обмена и структура сахароснижающей терапии по данным Федерального регистра сахарного диабета, статус 2017 г. Сахарный диабет. Т.21. № 3 (2018). С. 144-159.

4. Ефимов А.С., Орленко В.Л., Соколова Л.К. Сахарный диабет и его осложнения. Журн. практ. лікаря. 2003. №2. С.34-40.

5. IDF Diabetes Atlas 8th edition 2017 update, URL: https://www.diabete.qc.ca > getdocumen tutile > IDF-DA-8e-EN-finalR3

6. Diabetes. WHO 2018. https://www.who.int/news-room/fact-sheets/detail/diabetes

7. Паньків В. І. Цукровий діабет: визначення, класифікація, епідеміологія, фактори ризику. Международный эндокринологический журнал. 2013. №. 7 (55). С. 55-60.

8. Діабет в Україні. «Діафорум 2017». URL: https://www.unian.net/health/country/2233891v-ukraine-bolee-1-mln-300-tyisyach-lyudey-jivut-s-saharnyim-diabetom.html.

9. Shaw J.E., Sicree R.A., Zimmet P.Z. Diabetes Atlas: Global estimates of the prevalence of diabetes for 2010 and 2030. Diabetes Research and Clinical Practise. 2010.V.87. P. 4-14.

10. Распространенность сахарного диабета в Украине. URL: https://telegraf.com.ua/zhizn /zdorove/ 2195284-rasprostranennost-saharnogo-diabeta-v-ukraine-uvelichilas-v-poltora-raza.html.

11. Новаторские методы оказания помощи при хронических состояниях. Основные элементы для действий: глобальный доклад всемирной организации здравоохранения (ВО3, 2003). URL: https://www.who.int/chp/knowledge/publications/icccrussian.pdf/ua.

12. Inzucchi Silvio E., Bergenstal Richard M., Buse John B. [et al.] Management of Hyperglycemia in Type 2 Diabetes, 2015: A Patient-Centered Approach: Update to a Position Statement of the American Diabetes Association and the European Association for the Study of Diabetes. Diabetes Care. 2015. Vol. 38. N 1. P. 140-149.

13. Whitehead L, Seaton P. Whitehead L, Seaton P. The Effectiveness of Self-Management Mobile Phone and Tablet Apps in Long-term Condition Management: A Systematic Review. J Med Internet Res. 2016. V.18(5):e97.

14. Debon R., Coleone J.D., Bellei E.A., De Marchi A.C.B. Mobile health applications for chronic diseases: A systematic review of features for lifestyle improvement. Diabetes Metab Syndr. 2019. V13. N 4. P. 2507-2512.

15. Мамедов М.Н. Самоконтроль при сахарном диабете: применение современных технологий в домашних условиях. Медицинский совет. 2016. №13. С.95-98.

16. Древаль А.В., Редькин Ю.А. Роль самоконтроля в лечении сахарного диабета. Русский медицинский журнал. 2016. № 1. С. 38-40.

17. Балаболкин М.И., Клебанова Е.М., Креминская В.М. Лечение сахарного диабета и его осложнений (руководство для врачей). Москва: Медицина, 2005. 512 с.

18. Самсон О.Я., Большова О.В., Музь В.А. Особливості самоконтролю цукрового діабету у дітей і підлітків. Клінічна ендокринологія та ендокринна хірургія. 2010. № 2(31). С.42-47.

19. Отчет семинара по помповой инсулинотерапии. «Российская Диабетическая Ассоциация» ( 23-26 июня 2012). URL: http://rda.org.ru/doc/poland2012.htm.

20. Алгоритмы специализированной медицинской помощи больным сахарным диабетом /Под редакцией И.И. Дедова, М.В. Шестаковой, А.Ю. Майорова. 8-й выпуск. Москва: УП ПРИНТ, 2017. 112 с.

21. Карпельев В.А., Федоров Е.А., Филиппов Ю.И., Шестакова М.В. Интраперитонеальная инфузия инсулина при сахарном диабете: на пути к искусственной поджелудочной железе. Сахарный диабет. 2015. №3. С.32-45.

22. Riazi H., Larijani B.,Langarizadeh, M. And L. Shahmoradi. Managing diabetes mellitus using information technology: a systematic review. J Diabetes Metab Disord. 2015. V. 14. P. 49.

23. Jackson CL, Bolen S, Brancati FL, Batts-Turner ML, Gary TL. A systematic review of interactive computer-assisted technology in diabetes care: interactive information technology in diabetes care. J Gen Intern Med. 2006. V. 21. №2. P.105-110.

24. Saenz A, Brito M, Moron I, Torralba A, Garcia-Sanz E, Redondo J. Development and validation of a computer application to aid the physician's decision-making process at the start of and during treatment with insulin in type 2 diabetes: a randomized and controlled trial. J Diabetes Sci Technol. 2012. V.6 (3). P. 581-8. 
25. Тронько Н.Д., Халангот Н.Д. Использование компьютерных систем и информационных технологий в практической диабетологии. Ендокринологія. 2001. №1. С.89-94.

26. Marcolino MS, Maia JX, Alkmim MBM, Boersma E, Ribeiro AL. Telemedicine application in the care of diabetes patients: systematic review and meta-analysis. Plos One. 2013. V. 8(11). e79246.

27. Adaji A., Schattner P., Jones K. The use of information technology to enhance diabetes management in primary care: a literature review. Informatics in Primary Care. 2008. №16. P. 229-37.

28. Siriwardena LSAN, Sudarshana Wickramasinghe WA, Dussantha Perera KL, Marasinghe RB, Katulanda P, Hewapathirana R. A review of telemedicine interventions in diabetes care. $J$ Telemed Telecare. 2012.№18. P. 164-8.

29. Честнов. О.П., Бойцов С.А., Куликов А.А., Батурин Д.И. Мобильное здравоохранение: мировой опыт и перспективы. Профилактическая медииина. 2014. №17(4). С 3-9.

30. Bree Holtz, Carolyn Lauckner. Diabetes management via mobile phones: a systematic review. Telemedicine and e-Healt. 2012 .V. 18. № 3. P. 175-185.

31. Faraz S. Ahmad, Thomas Tsang. Diabetes Prevention, Health Information Technology, and Meaningful Use. American Journal of Preventive Medicine. 2013. V. 44.№4. S357-S363.

32. Pradeepa R, Prabu AV, Jebarani S, Subhashini S, Mohan V. Use of a large diabetes electronic medical record system in India: clinical and research applications. $J$ Diabetes Sci Technol .2011. №5(3). P.543-52.

33. World Health Organization.(2011).Use of glycated haemoglobin (HbA1c) in diagnosis of diabetes mellitus: abbreviated report of a WHO consultation.World Health Organization. URL: https://apps.who.int/iris/handle/10665/70523

34. Лавренюк Н.В., Кифоренко С.И., Котова А.Б., Иваськива Е.Ю. Информационнокомпьютерная поддержка принятия решений при ранней диагностике сахарного диабета. Кибернетика и вычисл. техника. 2009. Вып.157. С. 54-60.

35. Тронько М.Д., Сфімов А.С., Кравченко В.Ш. Рання діагностика цукрового діабету та його ускладнень. Лікар-інфо: портал про здоров'я. 2003. URL: http://www/likarsnfo/pro/43480/.

36. Ефимов А.С., Карабун П., Эпштейн Е.В. Ожирение и сахарный диабет. Киев: Здоровье, 1987. $144 \mathrm{c.}$

37. Ефимов А.С., Орленко В.Л., Соколова Л.К. Сахарный диабет и его осложнения. Журн. практ. лікаря. 2003. №2. С.34-40.

38. Принципы автоматического управления, их преимущества и недостатки. URL: https://studfiles.net/preview/4634773/page:13/.

39. Turksoy K., Cinar A. Adaptive control of artificial pancreas systems - a review. J Healthc Eng. 2014. V. 5(1). P. 1-22.

40. Cobelli C., Renard E., Kovachev BP. Artificial pancreas : past, present, future. Diabetes. 2011. V. 60. P. 2672-82.

41. Лебедева О., Лебедев И. Считалка калорий. URL: http://calories.ru/cgi-bin/calc.pl.

42. Кадомский Ю. Азбука диабета. Точечная интенсивная инсулинотерапия инсулинозависимого сахарного диабета. 2018. 129 c. URL: http://www.juri.dia-club.ru.

43. Школа диабета. Научись управлять диабетом. URL: https:/ https://shkoladiabeta.ru/.

44. Про затвердження Норм фізіологічних потреб населення України в основних харчових речовинах і енергії. Наказ 03.09.2017 № 1073 Міністерства охорони здоров’я України. URL: http://zakon2.rada.gov.ua/laws/show/z1206-17.

Отримано: 19.06.2019 
C.I. Кіфоренко ${ }^{l}$, д-р біол. наук, старш. наук. співроб., пров. наук. співроб. відд. застосування математичних і технічних методів у біології та медицині email: skifor@ukr.net T.M. Гонтар , канд. біол. наук, старш.наук. співроб., старш.наук. співроб. відд. застосування математичних і технічних методів у біології та медицині email:gtm_kiev@ukr.net В.Л. Орленко ${ }^{2}$, канд. мед. наук, старш.наук. співроб., зав. науково-консультативного відділу амбулаторно-профілактичної допомоги хворим 3 ендокринною патологією email: orleva@ukr.net

К.Ю. Іваськіва ${ }^{2}$, канд. мед. наук, старш. наук. співроб., науково-консультативний відділ амбулаторно-профілактичної допомоги хворим з ендокринною патологією email: k_iva@ukr.net Т.А. Обелець , молодш. наук. співроб., відд. застосування математичних і технічних методів у біології та медицині email:gtm_kiev@ukr.net

${ }^{1}$ Міжнародний науково-навчальний центр інформаційних технологій та систем НАН України та МОН України, пр. Акад. Глушкова, 40, м. Київ, 03187, Україна

${ }^{2}$ Інститут ендокринології та обміну речовин ім. В.П. Комісаренка НАМН України, вул. Вишгородська, 69. М. Київ, 04114 Україна

\section{ІНФОРМАЦІЙНА ТЕХНОЛОГІЯ ПІДТРИМКИ САМОКОНТРОЛЮ У ФОРМУВАННІ РАЦІОНАЛЬНОЇ ЖИТТЄДІЯЛЬНОСТІ У ПАЦІЄНТІВ ХВОРИХ НА ДІАБЕТ}

Вступ. Цукровий діабет - небезпечне, поширене хронічне ендокринне захворювання, в основі якого лежить розлад обміну речовин, пов'язаний, в першу чергу, з порушенням вуглеводного обміну. Забезпечення необхідності самостійного контролю за станом здоров'я хворих на діабет $є$ нагальною проблемою сьогодення. Використання засобів інформаційних технологій та мобільної медицини уможливлює підвищення ефективності самоконтролю пацієнтом стану свого здоров'я.

Метою статті є розроблення комплексної інформаційної технології для підвищення ефективності глікемічного самоконтролю у разі діабету на різних етапах лікувального процесу.

Результати. Запропоновано алгоритм визначення стану системи регуляції глікемії, в основу якого покладено аналіз результатів глюкозотолерантного тесту. Результатом $€$ розширена класифікаційна шкала регуляції глікемії - норма, зона ризику, порушена толерантність (латентна форма), діабет, що підвищує роздільну здатність стандартної методики і дає змогу своєчасно проводити заходи щодо застосування профілактичних дій для запобігання прояву реальних порушень в системі регуляції глікемії. Алгоритм програмно реалізовано у трьох варіантах: для комп'ютерів, планшетів і для мобільних пристроїв під ОС Андроїд. Розроблена інформаційна технологія підтримки прийняття рішень у виборі адекватного режиму активності та харчування хворих на діабет забезпечує визначення дисбалансу між енергією, яка поступає в організм разом 3 вибраним користувачем меню (набором продуктів і блюд) і енергією, яка витрачається за різних видів запланованої діяльності (фізичної, інтелектуальної тощо).

Висновки. Використання у розробленій технології принципу зовнішнього комбінованого регулювання, який поєднує позитивні якості керування за збуренням і керування зі зворотним зв'язком за відхиленням, забезпечило можливість підвищити ефек- 
тивність самоконтролю пацієнтом стану свого здоров'я. Реалізація технології у трьох модифікаціях: для стаціонарних комп'ютерів, планшетів і для мобільних пристроїв під OC Андроїд дає змогу зробити доступнішою інформаційну допомогу користувачеві 3 різним ступенем порушення регуляції вуглеводного обміну: на етапі доклінічної допомоги та на етапі лікування.

Ключові слова: інформачійна технологія, иукровий діабет, самоконтроль стану здоров'я пацієнтом, приципи керування, мобільні пристрої.

С.И. Кифоренко ${ }^{\prime}$, д-р биол. наук, старш. науч. сотр., вед. науч. сотр. отд. применения математических и технических методов в биологии и медицине email: skifor@ukr.net

T.M. Гонтарь ${ }^{1}$, канд. биол. наук, старш.науч. сотр.

отд. применения математических и технических

методов в биологии и медицине

email:gtm_kiev@ukr.net

В.Л. Орленко ${ }^{2}$, канд. мед. наук, старш. науч. сотр., зав. научно-консультативного отдела

амбулаторно-профилактической помощи

пациентам с эндокринной патологией

email: orleva@ukr.net

К.Ю. Иваськива ${ }^{2}$, канд. мед. наук, старш.науч. сотр., научно-консультативный отд. амбулаторно-профилактической

помощи пациентам с эндокринной патологией

email: k_iva@ukr.net

T.А. Обелець ${ }^{1}$, младш. науч. сотр.,

отд. применения математических и технических методов

в биологии и медицине

email:gtm_kiev@ukr.net

${ }^{1}$ Международный научно-учебный центр информационных

технологий и систем НАН Украины и МОН Украины,

пр. Акад. Глушкова, 40, г. Киев, 03187, Украина

${ }^{2}$ Інститут эндокринологии и обмена веществ

им. В.П. Комиссаренко НАМН Украины,

ул. Вышгородская, 69. г. Киев, 04114 Украина

\section{ИНФОРМАЦИОННАЯ ТЕХНОЛОГИЯ ПОДДЕРЖКИ САМОКОНТРОЛЯ ПРИ ФОРМИРОВАНИИ РАЦИОНАЛЬНОГО ОБРАЗА ЖИЗНИ ДЛЯ БОЛЬНЫХ ДИАБЕТОМ}

Предложен алгоритм определения состояния системы регуляции гликемии, в основу которого положен анализ результатов глюкозотолерантного теста. Результатом является расширенная классификационная шкала регуляции гликемии - норма, зона риска, нарушенная толерантность (латентная форма), диабет - что повышает разрешающую способность стандартной методики и позволяет своевременно проводить мероприятия по применению профилактических действий для предотвращения проявления реальных нарушений в системе регуляции гликемии. Алгоритм программно реализован в трех вариантах: для компьютеров, планшетов и для мобильных устройств под ОС Андроид.

Разработанная информационная технология поддержки принятия решений в выборе адекватного режима активности и питания больных диабетом дает возможность определить дисбаланс между энергией, поступающей в организм вместе с выбранным пользователем меню (набором продуктов и блюд) и энергией, которая расходуется на различные виды запланированной деятельности (физической, интеллектуальной и т.д.).

Ключевые слова: информационная технология, сахарный диабет, самоконтроль состояния здоровья, приципы управления, мобильные приложения. 